\title{
Spinal myoclonus selectively affecting the platysma after cervical laminectomy
}

Akiyuki Uzawa, MD, PhD, Takeo Furuya, MD, PhD, Seiji Ohtori, MD, PhD, and Satoshi Kuwabara, MD, PhD Neurology ${ }^{\circledR}$ 2018;91:45-46. doi:10.1212/WNL.0000000000005746

Correspondence

Dr. Uzawa

auzawa@chiba-u.jp

Figure Spinal cord MRI and schema
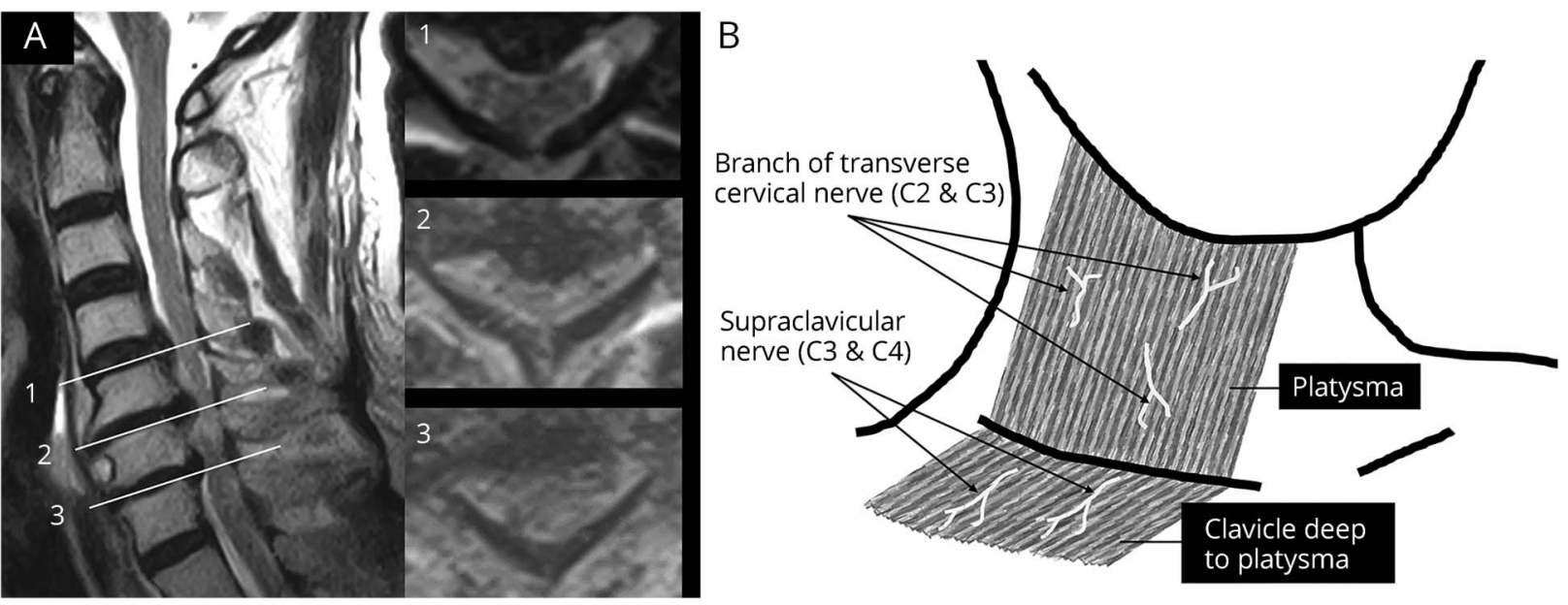

(A) C4-C7 canal stenosis on spinal cord MRI. (B) Schema of platysma and platysma-related nerves.

A 70-year-old man on hemodialysis for diabetic nephropathy experienced gradually worsening tetraparesis and sensory disturbance below C6. Spinal cord MRI revealed canal stenosis of C4-C7 (figure, A) and laminectomy was performed. On postoperative day 1, he developed intermittent bilateral platysma myoclonus (video) without facial muscle weakness. The symptom resolved spontaneously on postoperative day 2 .

The platysma muscle is innervated by the facial nerve and the high cervical cord. ${ }^{1}$ The etiology of platysma myoclonus, which has never been reported, remains uncertain. This patient might be manifesting a form of spinal myoclonus involving the branches of the transverse cervical nerve and supraclavicular nerves (figure, B). We speculate that nerve tethering due to spinal cord shifting ${ }^{2}$ or transient edema after laminectomy caused spinal root stimulation leading to the generation of this transient myoclonus.

\section{Author contributions}

Akiyuki Uzawa: drafting/revising the manuscript, accepts responsibility for conduct of research and final approval. Takeo Furuya: drafting/revising the manuscript, study concept or design, accepts responsibility for conduct of research and final approval, study supervision. Seiji Ohtori: drafting/revising the manuscript, accepts responsibility for
MORE ONLINE

- Video 
conduct of research and final approval, study supervision. Satoshi Kuwabara: drafting/revising the manuscript, accepts responsibility for conduct of research and final approval, study supervision.

\section{Study funding}

No targeted funding reported.

\section{Disclosure}

The authors report no disclosures relevant to the manuscript. Go to Neurology.org/N for full disclosures.

\section{References}

1. Ogawa Y, Sakakibara R. Platysma sign in high cervical lesion. J Neurol Neurosurg Psychiatry 2005;76:735.

2. Nassr A, Eck JC, Ponnappan RK, Zanoun RR, Donaldson WF III, Kang JD. The incidence of C5 palsy after multilevel cervical decompression procedures: a review of 750 consecutive cases. Spine 2012;37:174-178.

\section{Neurology.org/N Offers Important Information to Patients and Their Families}

The Neurology ${ }^{\circledR}$ Patient Page provides:

- A critical review of ground-breaking discoveries in neurologic research that are written especially for patients and their families

- Up-to-date patient information about many neurologic diseases

- Links to additional information resources for neurologic patients

All Neurology Patient Page articles can be easily downloaded and printed, and may be reproduced to distribute for educational purposes. Click on the 'Patients' link on the home page (Neurology.org/N) for a complete index of Patient Pages.

\section{Share Your Artistic Expressions in Neurology 'Visions'}

AAN members are urged to submit medically or scientifically related artistic images, such as photographs, photomicrographs, and paintings, to the "Visions" section of Neurology ${ }^{\oplus}$. These images are creative in nature, rather than the medically instructive images published in the NeuroImages section. The image or series of up to six images may be black and white or color and must fit into one published journal page. Accompanying description should be 100 words or less; the title should be a maximum of 96 characters including spaces and punctuation.

Please access the Author Center at NPub.org/authors for full submission information.

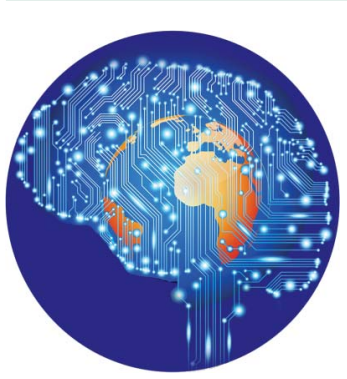

\section{Practice Current: An interactive exchange on controversial topics}

Share your own best practices.

Read commentary with expert opinion.

Explore results on an interactive world map.

NPub.org/NCP/practicecurrent

Neurology ${ }^{\circledR}$ Clinical Practice 


\section{Neurology}

Spinal myoclonus selectively affecting the platysma after cervical laminectomy
Akiyuki Uzawa, Takeo Furuya, Seiji Ohtori, et al.

Neurology 2018;91;45-46

DOI 10.1212/WNL.0000000000005746

This information is current as of July 2, 2018

\section{Updated Information \&} Services

\section{References}

Subspecialty Collections

Permissions \& Licensing

Reprints including high resolution figures, can be found at: http://n.neurology.org/content/91/1/45.full

This article cites 2 articles, 0 of which you can access for free at: http://n.neurology.org/content/91/1/45.full\#ref-list-1

This article, along with others on similar topics, appears in the following collection(s):

All Clinical Neurology

http://n.neurology.org/cgi/collection/all_clinical_neurology

All Movement Disorders

http://n.neurology.org/cgi/collection/all_movement_disorders

All Spinal Cord

http://n.neurology.org/cgi/collection/all_spinal_cord

Myoclonus

http://n.neurology.org/cgi/collection/myoclonus

Information about reproducing this article in parts (figures,tables) or in its entirety can be found online at:

http://www.neurology.org/about/about_the_journal\#permissions

Information about ordering reprints can be found online:

http://n.neurology.org/subscribers/advertise

Neurology ${ }^{\circledR}$ is the official journal of the American Academy of Neurology. Published continuously since 1951, it is now a weekly with 48 issues per year. Copyright () 2018 American Academy of Neurology. All rights reserved. Print ISSN: 0028-3878. Online ISSN: 1526-632X.

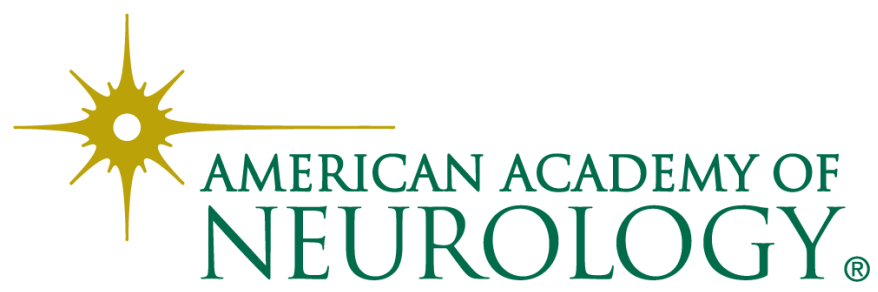

